\title{
Effect of a Mushroom (Coriolus versicolor) Based Probiotic on the Expression of Toll-like Receptors and Signal Transduction in Goat Neutrophils
}

\author{
Kingsley Ekwemalor ${ }^{1}$, Emmanuel Asiamah $^{1} \&$ Mulumebet Worku $^{2}$ \\ ${ }^{1}$ Department of Energy and Environmental Systems, North Carolina Agricultural and Technical State University, \\ USA \\ ${ }^{2}$ Department of Animal Sciences, North Carolina Agricultural and Technical State University, USA \\ Correspondence: Mulumebet Worku, Department of Animal Science, North Carolina Agricultural and Technical \\ State University, 1601 E Market Street, 27411, Greensboro, USA. E-mail: Worku@ncat.edu
}

Received: September 13, 2016

Accepted: September 28, 2016

Online Published: October 21, 2016

doi:10.5539/jmbr.v6n1p71

URL: http://dx.doi.org/10.5539/jmbr.v6n1p71

\begin{abstract}
Neutrophils recognize and destroy pathogens through activation of the Toll like receptor (TLR) system as part of the inflammatory response of innate immunity. The expression and modulation of genes in the TLR signaling pathway in caprine blood neutrophils was investigated. Following initial screening for infection, goats $(\mathrm{N}=15)$ were assigned to three groups of five $(\mathrm{n}=5)$ individuals. Goats were drenched daily with $10 \mathrm{~mL}$ of powdered CorPet (Mycology labs Inc) soaked in hot (treatment I) or cold (treatment II) sterile filtered endotoxin free water, for a 4-week period. A control group of five age-matched goats received sterile water (treatment III). Blood was collected weekly and analyzed for packed cell volume and white blood cell differential counts. At weeks 1 and 4 neutrophils were isolated, using differential centrifugation and hypotonic lysis of red blood cells. The concentration and purity of total RNA isolated using Trizol was determined on a Nanodrop spectrophotometer. The RETROscript kit was used to synthesize cDNA. The expression of 84 genes in the human TLR signaling pathway RT ${ }^{2}$ PCR Array was evaluated using real time PCR and the Livak method. The house keeping gene GAPDH was used to normalize the data. At week 1 untreated goats expressed 48 genes in the pathway. Goat neutrophils expressed 10 TLRs. Mushroom extracts modulated expression of and signaling by TLR. These results will help in the definition of the role of TLR expression in neutrophils and its contribution to goat innate immunity. Further this may aid in the design of therapeutics for goat health.
\end{abstract}

Keywords: goat, mushroom, neutrophil, toll-like receptors

\section{Introduction}

Goats live in a wide variety of microbe-rich environments. It is crucial to have a sensitive innate defense mechanism which relies in part by recognizing conserved molecules that are unique to some classes of potential pathogens. The innate immune system is based principally on physical and chemical barriers to infection, as well as on different cell types recognizing invading pathogens and activating antimicrobial immune responses (Basset et al., 2003).

They are key innate immune effector cells that provide early defense against invading microorganisms (Prince et al., 2011). They initiate antimicrobial and proinflammatory functions. They transit rapidly to sites of infection, where they limit infection and allow recruitment and activation of other immune cells through the release of inflammatory mediators and antimicrobial products, resulting in pathogen clearance and ultimately, in the initiation of an adaptive response (Yamashiro et al., 2001). Primary sensing of pathogen associated molecular patterns (PAMPs) to alert the innate immune system is achieved by an array of germ-like encoded receptors known as pattern recognition receptors (PRRs) (Tirurugaan et al., 2010). One of the important PRRs that play a key role in innate immunity is the type 1 transmembrane proteins called Toll-like Receptors (TLRs). Toll-like Receptors recognize microbial markers namely proteins, carbohydrates, lipids, nucleic acids and/or their combinations in an efficient, non-self-reactive manner to initiate a complex signaling cascade and activate a wide variety of transcription factors and inflammatory cytokines (Akira \& Takeda, 2004). These cell surface molecules also activate complement, phagocytosis, inflammation and apoptosis in response to pathogen 
detection (West et al., 2006) finally culminating in the initiation of adaptive immunity through the induction of pro-inflammatory mediators (Janeway \& Medzhitov, 2002).

Appropriate recognition of the invading pathogen is fundamental for the prompt and proper activation of the immune response. Their targets include bacteria, fungi, protozoa, viruses, virally infected cells and tumor cells. This function is facilitated by the expression of TLR family members by neutrophils, allowing the recognition of an extensive repertoire of PAMPs and thus triggering the response of invading pathogens (Prince et al., 2011). Pathogen associated molecular pattern such as beta-glucans, which form the main cell wall skeleton in mushrooms and as fungi, are recognized immediately by PRR (Kumagai \& Akira, 2010), such as TLR2, dectin-1 and CR3. Mushrooms activate B-lymphocytes and macrophages through TLR, modulating the immune system and inducing the production of cytokines (Liao et al., 2004).

Mushrooms are known for their nutritional and medicinal value and also for the diversity of bioactive compounds they contain. The mushroom Coriolus versicolor (CV) has been reported to have an effect by boosting suppressed immune function, extending the survival rate and improving quality of life of cancer patients (LY Eliza et al., 2014). Various products derived from this mushroom and claimed to have medicinal value are commercially available. The active ingredients in $C V$ are polysaccharides, in particular the polysaccharide krestin (PSK) and polysaccharide-peptide (PSP) (Chan \& Yeung, 2006). They exert their therapeutic effects by modulating the host's immune response. Both preclinical and clinical evidences have demonstrated that extracts from $C V$ display a wide array of biological activities, including stimulatory effects on the immune system and inhibition of cancer growth (Zhou et al., 2007). The aqueous extract of mushrooms has been found to be effective in activating $\mathrm{T}$ and $\mathrm{B}$ lymphocytes, macrophages, natural killer cells, and lymphocyte-activated killer cells, as well as promoting the production of antibodies and various cytokines, such as IL-2 and IL-6, and tumor necrotic factor (TNF) in vivo (Lull et al., 2005, Rowan et al., 2003). CV can remedy intestinal disorders, suppress microbial infection the immune response (Cui \& Chisti, 2003) and improve immune function by increasing neutrophil count (Tsang et al., 2003). The objective of this study was to determine the effect of a mushroom based probiotic on the expression of genes in the TLR signaling pathway in Caprine blood neutrophils and to evaluate their modulation.

\section{Materials and Methods}

\subsection{Animals}

Fifteen clinically healthy female SpanishXBoer goats from the goat herd at the North Carolina Agricultural and Technical University Small Ruminant Research Unit were used in this study. Animals were clinically healthy and not under any treatment. Initial sampling was carried out to determine the health of the animals. The study was approved by the Institutional Animal Care and Use Committee.

\subsection{Preparation of Mushroom Extracts}

CorPet (CV) powder was purchased from Mycology Research Labs Ltd (United Kingdom). It contains Coriolus versicolor, Microcrystalline cellulose (bulking agent), Silica (anti-caking agent), vegetable and Magnesium. Hot extracts (treatment I) was prepared by weighing $25 \mathrm{~g}$ of CorPet powder in $250 \mathrm{ml}$ of sterile endotoxin free water and heating to $100^{\circ} \mathrm{C}$ with stirring for 20 minutes. Twenty-five (25) grams of CorPet was stirred in $250 \mathrm{ml}$ of sterile endotoxin free distilled water and served as cold extract (treatment II). The extracts were left to cool and then stored at $4^{0} \mathrm{C}$ until it was used. Distilled water (treatment III) served as control.

\subsection{CorPet Drench Administration}

Ten (10) $\mathrm{mL}$ of the hot and cold extracts were given to each goat (5 goats per group) daily. Ten (10) $\mathrm{mL}$ of distilled water was administered to the control group. Extracts were administered daily for 30 days using a $10 \mathrm{ml}$ syringe.

\subsection{Neutrophil Isolation}

Peripheral blood $(15 \mathrm{ml})$ was collected from the jugular vein into vacutainer tubes containing anticoagulant weekly and analyzed for packed cell volume, white blood cell differential count and live cell count using TC20 (Biorad). Neutrophils were isolated from blood samples by differential centrifugation and hypotonic lyses of the red blood cells according to the modified procedure of Carlson and Kaneko (1973). The cell pellet was resuspended in $5 \mathrm{ml}$ of sterile phosphate-buffered saline; $\mathrm{pH}$ 7.4. All reagents used in this study were prepared using sterile endotoxin free water. Endotoxin assay was performed as described by Adjei-Fremah et al. (2016a). Viable cells were counted on a TC10 (Biorad) cell counter using Trypan blue dye exclusion technique. Isolated neutrophils were adjusted to a concentration of $1 \times 10^{7}$ viable cells $/ \mathrm{ml}$ in PBS and used for RNA extraction. The 
white blood cell differential counts were determined as described by Schaim et al. (1975). White blood cell differential counts were performed using an Olympus B 201 microscope using a 100x magnification.

\subsection{Isolation of RNA}

Total RNA, was isolated using Tri-reagent (Molecular Research Centre, Inc. Cincinnati, OH) following extraction procedure previously described by Asiamah et al. (2016). The quantity and quality of RNA was measured with the ND-1000 UV/VIS Nanodrop spectrophotometer (260 nm and 260/280 nm respectively). RNase free water was used as a blank.

\subsection{Real Time PCR}

Reversed transcription was performed using Oligo (dT) primers with 2 ug of the total RNA from each treatment group using a Complementary DNA (cDNA) RETRO script Kit (Ambion Inc., Austin, TX) following the manufacturer's instructions. The cDNA products were measured for purity and concentration using the Nanodrop spectrophotometer (NanoDrop Technologies). Quantification was performed in the CFX96 ${ }^{\mathrm{TM}}$ Biorad Real-Time PCR detection system with the addition of the dye SYBR Green using the Qiagen Human TLR RT-PCR array (Qiagen, Valencia, CA) containing specific primer sets for 84 relevant TLR pathway genes, 5 housekeeping genes, and 2 negative controls (Table 1). Gene expression was normalized to GAPDH (housekeeping genes) to determine the fold change in gene expression between test and control samples by using the $2^{-\Delta \Delta \mathrm{Ct}}$ method (Livak \& Schmittgen, 2001).

Table 1. Functional gene grouping Qiagen human TLR RT-PCR

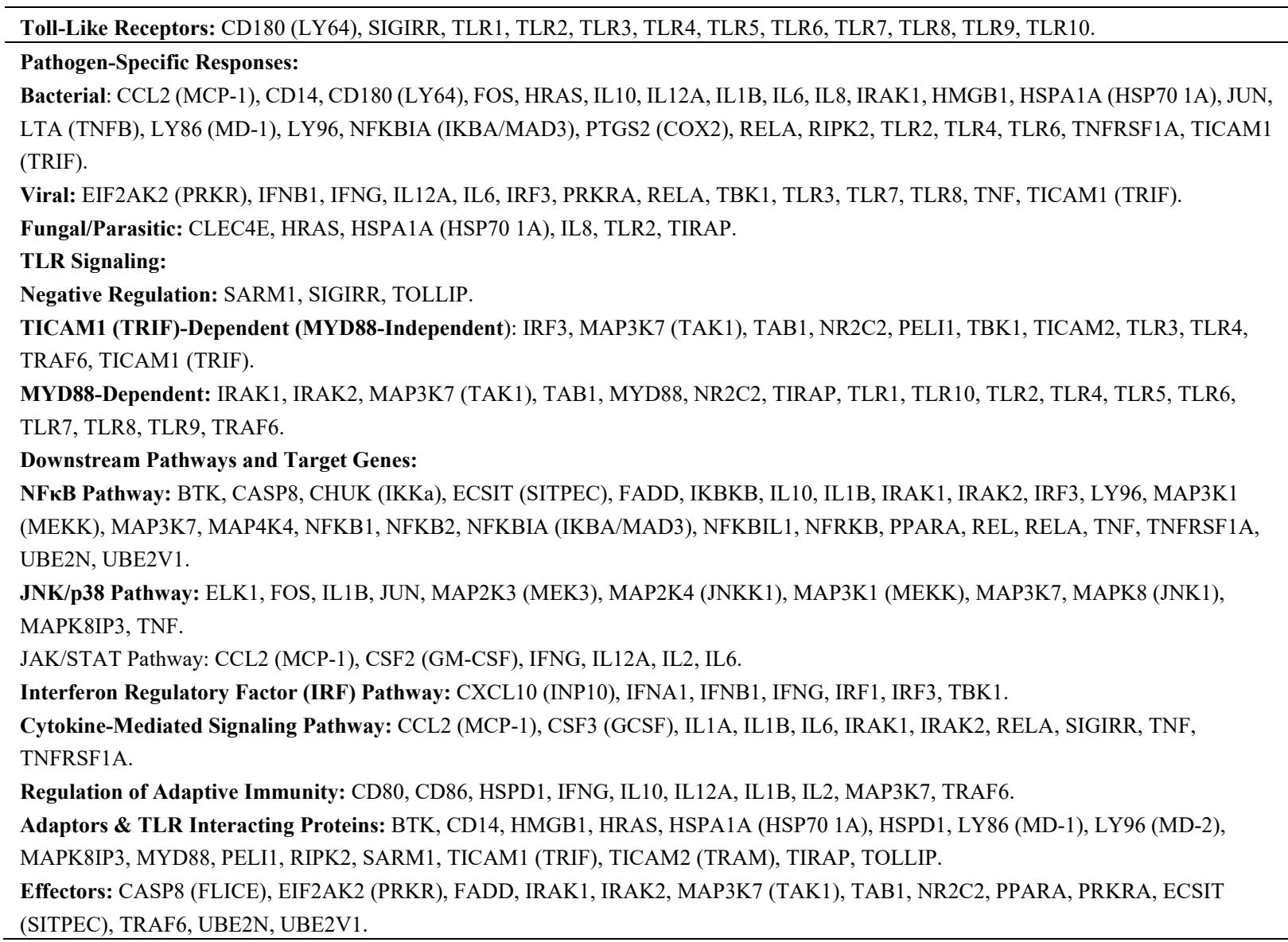

\subsection{Statistical Analysis}

Statistical analysis was conducted using the statistical analysis software SAS (SAS Institute Inc., Cary, NC). Analysis of variance was performed to evaluate the significance of treatment differences on RNA concentration $\mathrm{p}<0.05$. 


\section{Results}

This study evaluated the expression and modulation of genes in the TLR signaling pathway in goat neutrophils. There was no significant difference $(\mathrm{p}>0.05)$ in the percentages of neutrophils, lymphocytes, monocytes, basophils and eosinophils between treatments and control groups (Figure 1). There was no difference in RNA concentration between treatment and control groups $(\mathrm{p}<0.42)$. There was an observable decrease in RNA concentration in samples from treated goats compared to controls at week 1 and week 3 compared to an increase at week 2 and 4 (Figure 2).

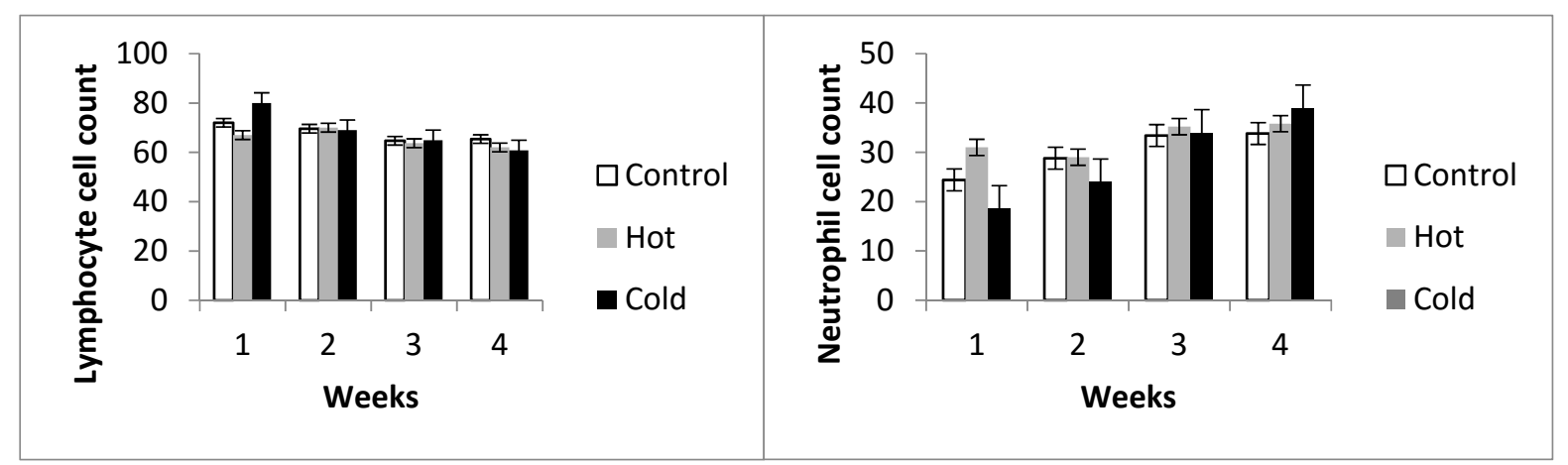

Figure 1. Effect of CorPet extract on white blood cell count

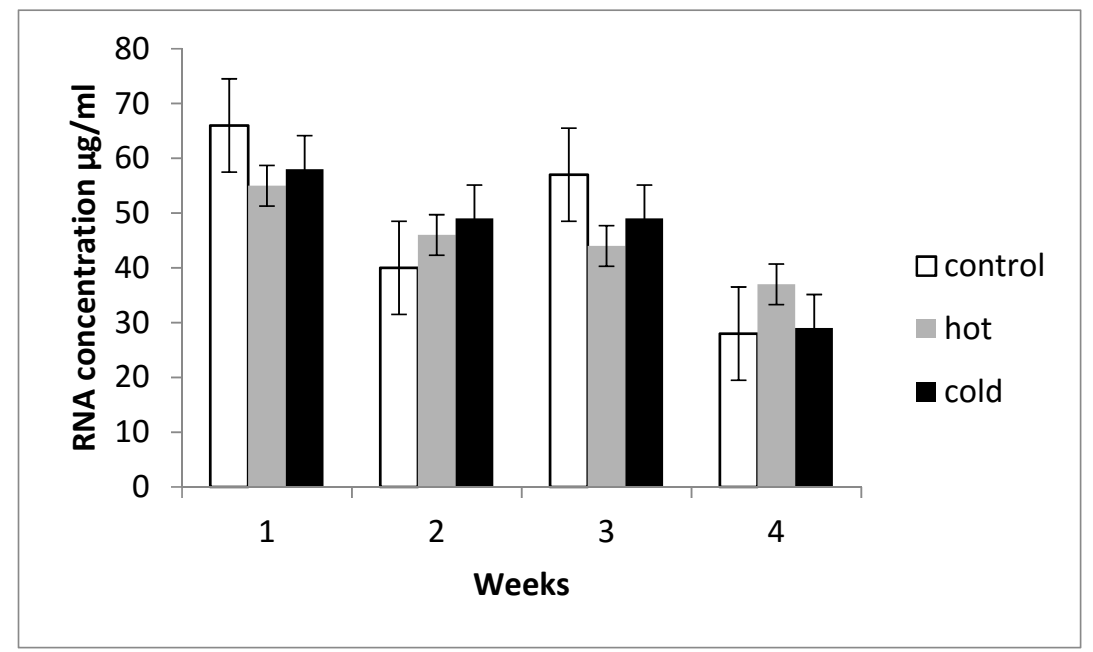

Figure 2. Effect of CorPet on RNA concentration over a week period

Genes on the human TLR array associated with fungal and parasitic response, toll-like receptor signaling, cytokine signaling and downstream signaling of toll-like receptors (Table 1) were expressed in goat peripheral blood neutrophils. At the beginning of the study 48 genes were expressed in untreated goats. Treatment with $\mathrm{CV}$ modulated the expression of these genes. After 4 weeks, hot extract modulated the expression of 40 genes; cold extract modulated the expression of 6 genes while goats from the control group expressed 8 genes (Table 2).

Table 2. Summary of number of genes expressed.

\begin{tabular}{lcc}
\hline Treatment & \multicolumn{2}{c}{ Number of genes expressed } \\
\cline { 2 - 3 } & Week 1 & Week 4 \\
\hline Control & 14 & 7 \\
Hot & 40 & 84 \\
Cold & 47 & 6 \\
\hline
\end{tabular}




\subsection{Effect of Treatment on 84 Genes in TLR Signaling Pathway}

In the control group animals 14 genes were expressed in week 1. These genes include CASP8, CCL2, IFNB1, IL1B, IRF3, MAP3K47, MAPK8, NFRKB, SARMI, TBK1, TLR2, TLR8, TLRF6 and UEE2VI. After 4 weeks 7 genes were expressed which included CLEC4E, CXCL10, ELK1, NFKB1L1, TLR 8, UBE2N and UBE2V1. Toll-like receptor 2 and UBE2VI were the genes expressed in week 1 and week 4. Both genes were down-regulated. These genes are not associated with fungi detection via PRR.

In the hot extract treatment group 48 genes were expressed in week 1. Following treatment, after 4 weeks all 84 genes were expressed in the TLR signaling pathway. Functional grouping of genes associated with fungal and toll-like receptors are listed in Table 3.

Table 3. Functional grouping of differentially expressed genes for the hot treatment group after 4 weeks

\begin{tabular}{ll}
\hline Functional group & Gene \\
\hline Fungal/parasitic & CLEC4E, HRAS, HSPA1A (HSP70 1A), IL8, TLR2, TIRAP. \\
Toll-like receptors & CD180 (LY64), SIGIRR, TLR1, TLR2, TLR3, TLR4, TLR5, TLR6, TLR7, TLR8, \\
& TLR9, TLR10. \\
\hline
\end{tabular}

Genes with a high fold change include MAPK8, NFKB2, PPARA, TOLLIP, TNFRSF1A, IRAK1 and CSF3 (Table 4).

Table 4. Differentially expressed genes and fold change in expression of animals drenched with hot extract treatment

\begin{tabular}{lll}
\hline Gene & Function & Fold change \\
\hline MAPK8 & Involved in a wide variety of cellular processes such as proliferation, & 425 \\
& differentiation, transcription regulation and development & \\
NFKB2 & Central activator of genes involved in inflammation and immune function & 2 \\
PPARA & Affects the expression of target genes involved in cell proliferation, cell & 596 \\
& differentiation and in immune and inflammation responses & \\
TOLLIP & Protein that interacts with several Toll-like receptor (TLR) signaling cascade & 328 \\
& components & \\
IRAK1 & Responsible for IL1-induced upregulation of the transcription factor NF-kappa B & 107 \\
\hline
\end{tabular}

In the cold treatment group 48 genes were expressed in week 1. After 4 weeks 6 genes were expressed. These genes include: MAK2K3, CXCL10, ELK1, FOS, MYD88 and UBE2V1. Genes that were common in both week one and week 4 (CXCL10, MAK2K3 and MYD88) were down regulated.

\subsection{Effect of Treatment on Toll-Like Receptors}

In goat neutrophils all 10 TLR were expressed. In the control group 2 TLR were expressed at week 1 . After 4 weeks only 1 TLR was expressed. In the hot extract group, 3 TLR were expressed at week 1 . After 4 weeks the hot extract induced the expression of all 10 toll-like receptors. In the cold extract group 6 TLR were expressed in week 1 but after 4 weeks there was no expression of TLR observed (Table 5).

Table 5. Effect of treatment on TLR expression.

\begin{tabular}{lll}
\hline Treatment & week & Toll-like Receptor \\
\hline Control & 0 & TLR2, TLR8 \\
Control & 4 & TLR8 \\
Hot & 0 & TLR4, TLR5, TLR7 \\
Hot & 4 & TLR1, TLR2, TLR3, TLR4, TLR5, TLR6, TLR7, TLR8, TLR9, TLR10 \\
Cold & 0 & TLR4, TLR5,TLR6, TLR7, TLR9, TLR10 \\
Cold & 4 & - \\
\hline
\end{tabular}


There was variability of TLR expressed among animals which can be attributed to genetic variability. Also there was variation of TLR expressed in the hot and cold treatment groups which can also be attributed to extract preparation method. Treatment with CV impacted the expression of genes important to TLR-mediated signal transduction in goat blood. Thus extract preparation had an effect on gene expression.

\section{Discussion}

Probiotics are nutritional supplements containing potentially beneficial microorganisms which confer beneficial health effects in variety of conditions and diseases in animals. In this study, the effect of a mushroom (Coriolus versicolor) based probiotics on the expression and modulation of genes in the TLR signal transduction pathway was evaluated in goat neutrophils. Hot extract treatment of CV had an effect on the expression of 6 TLRs. Ten TLR's have been identified in goats and expression has been reported in different tissue (Dhanasekaran et al., 2014, Tirumurugaan et al., 2010, Worku et al., 2016), however there are no reports regarding the expression of TLR in goat neutrophils. The TLRs recognize conserved PAMPs that are unique to microorganisms and are absent from higher eukaryotes (Han et al., 2003). The various TLRs exhibit different patterns of expression. The TLR1 family (TLR1, 2, 6 and 10) is involved in the recognition of gram-positive and gram-negative bacteria and heterodimers of TLR1 or TLR6 with TLR2 are crucial for the identification of several PAMPs (Kwong et al., 2011). Batbayar et al., (2011) reported that expression of TLR2, TLR4 and TLR6 was increased by $\beta$-glucan from Ganoderma lucidum which corresponds to the results obtained in this study. Results have shown that fungi binds to fungal ligand recognition regions on TLR1, 2, 4, 5, 6 and 10 which are found on the cell surface (Sasai \& Yamamototo, 2013). This report corresponds to the expression of these TLRs in our study with the exception of TLR 3, 7,8 and 9. Result showed that there was variation in expression of TLR among animals. Goyal et al., (Goyal et al., 2012) reported a nucleotide polymorphism observed in TLR7 gene of 24 goats representing 12 different breeds. Also in another study conducted by Zhou and Hickford (2008), they detected 5 nucleotide polymorphisms of TLR4 using 374 New Zealand goats of different breeds. These results correspond to the variation in expression of TLR in our study and can be exploited for association with disease susceptibility in goats.

Binding of ligands to TLRs triggers at least two important cell signaling pathways. One pathway involves MyD88, an adaptor protein shared by most of the TLRs that leads to the activation of the transcription factor NF- $\mathrm{KB}$ resulting in the release of pro-inflammatory cytokines (Raja et al., 2011, Adjei-Fremah et al., 2016b). Administration of $\mathrm{CV}$ modulated the expression of genes involved in multiple signaling pathways such as TLR-mediated signaling induction pathway, nuclear factor $\mathrm{\kappa B}(\mathrm{NF}-\mathrm{\kappa B})$, jun N-terminal kinase (JNK) and p38 mitogen-activated protein kinase (MAPK), janus kinase/signal transducers and activators of transcription (JAK-STAT), interferon regulatory factor (IFN) and cytokine mediated signaling pathways. Studies have shown that NF- $\mathrm{KB}$ plays a crucial role in immune responses and is an important transcriptional regulator of inflammatory cytokine genes. Yang et al. (2015) reported that polysaccharide from the CV activates mouse B cells through the MAPK and NF-kB signaling pathways. Also studies by Liu et al., (Liu et al., 2016) reported that extracts from shiitake mushroom (Lentinula edodes) induced the production of G-CSF, GM-CSF, M-CSF by activating the MAPKT/NF- $\kappa B$ signaling pathway in bone marrow cells. This corresponds with our results with the expression of genes involved in the MAPK and NF- $\mathrm{BB}$ signaling pathways. Previous study in our lab also shows that CV induced the secretion of G-CSF and GM-CSF (Ekwemalor, 2015).

Innate immunity can be stimulated by the activation of pattern recognition receptors. TLR's recognize pathogen-associated molecular patterns (PAMPs) that are expressed on infectious agents, and mediate the production of cytokines necessary for the development of effective immunity. Mushrooms which have $\beta$-glucans as their major component appear to have an important role in the innate immune response to fungal pathogens and in initiating a protective adaptive response (Brown \& Gordon, 2003). Several receptors for $\beta$-glucans acting as PRRs have been identified to date include Dectin-1, complement receptor 3 and TLR (Kang et al., 2013). Studies have suggested that polysaccharides from Ganoderma lucidum (Reishi) and Phellinus linteus extracts can act through TLR pathways to induce inflammatory responses in mouse cells (Prince et al., 2011).

Our results show a systemic effect of oral administration of CorPet probiotics which had an effect on TLR signal transduction in neutrophil in goat peripheral blood. Thus evidence is presented for activation of caprine neutrophils through dietary supplements such as probiotics. Specifically the expression and modulation of all ten TLR in goat neutrophils is presented. The method of extract (hot or cold) preparation may impact the PAMPs detected by neutrophils and provides support for opportunities for differential of TLR by pathogens and therapeutics in goat neutrophils. The possible difference in extract preparation between hot and cold extracts might be as a result of heating. Studies have shown differences in the effect of aqueous preparation as hot or cold formulation (Jung et al., 2014), but obvious reason needs to be clarified through further studies. 


\section{Conclusion}

We report the expression and modulation of genes in the TLR signal transduction pathway in goat neutrophils. In light of the critical role of TLR in controlling bacterial infections the expression and modulation of these genes may be critical to goat health and modulation of innate immunity using mushroom based probiotics. The expression of 10 TLRs in goat neutrophils has implications for further understanding of innate immunity in goats and efforts to modulate it through novel therapeutics. Our findings illustrate a repertoire of TLRs associated with inflammatory activation in goats, and they encourage further exploration.

\section{Acknowledgements}

We appreciate the assistance of Gary Summers and Hamid Ismail during sample collection and Tiffany Martin, Jordan Page and Allie McMahan for their assistance in this project. Funding support was from USDA project NC.X-271-5-13-120-1, Modulation of Receptor Cross-Talk for cattle, Sheep and Goat Innate Immunity.

\section{References}

Adjei-Fremah, S., Asiamah, E. K., Ekwemalor, K., Jackai, L., Schimmel, K., \& Worku, M. (2016). Modulation of Bovine Wnt Signaling Pathway Genes by Cowpea Phenolic Extract. Journal of Agricultural Science, 8(3), 21. http://dx.doi.org/10.5539/jas.v8n3p21

Adjei-Fremah, S., Ekwemalor, K., Asiamah, E., Ismail, H., \& Worku, M. (2016). Transcriptional profiling of the effect of lipopolysaccharide (LPS) pretreatment in blood from probiotics-treated dairy cows. Genomics Data, 10, 15-18. http://dx.doi.org/10.1016/j.gdata.2016.08.016

Akira, S., \& Takeda, K. (2004). Toll-like receptor signalling. Nature reviews immunology, 4(7), 499-511. http://dx.doi.org/10.1038/nri1391

Asiamah, E. K., Adjei-Fremah, S., Osei, B., Ekwemalor, K., \& Worku, M. (2016). An Extract of Sericea Lespedeza Modulates Production of Inflammatory Markers in Pathogen Associated Molecular Pattern (PAMP) Activated Ruminant Blood. Journal of Agricultural Science, 8(9), 1. http://dx.doi.org/10.5539/jas.v8n9p1

Basset, C., Holton, J., O’Mahony, R., \& Roitt, I. (2003). Innate immunity and pathogen-host interaction. Vaccine, 21, S12-S23. http://dx.doi.org/10.1016/S0264-410X(03)00195-6

Batbayar, S., Kim, M. J., \& Kim, H. W. (2011). Medicinal Mushroom Lingzhi or Reishi, Ganoderma lucidum (W. Curt.: Fr.) P. Karst., $\beta$-Glucan Induces Toll-like Receptors and Fails to Induce Inflammatory Cytokines in NF-kB Inhibitor-Treated Macrophages. International journal of medicinal mushrooms, 13(3). http://dx.doi.org/10.1615/IntJMedMushr.v13.i3.10

Brown, G. D., \& Gordon, S. (2003). Fungal $\beta$-glucans and mammalian immunity. Immunity, 19(3), 311-315. http://dx.doi.org/10.1016/S1074-7613(03)00233-4

Carlson, G. P., \& Kaneko, J. J. (1973). Isolation of leukocytes from bovine peripheral blood. Experimental Biology and Medicine, 142(3), 853-856. http://dx.doi.org/10.3181/00379727-142-37131

Chan, S. L., \& Yeung, J. H. (2006). Effects of polysaccharide peptide (PSP) from Coriolus versicolor on the pharmacokinetics of cyclophosphamide in the rat and cytotoxicity in HepG2 cells. Food and Chemical Toxicology, 44(5), 689-694. http://dx.doi.org/10.1016/j.fct.2005.10.001

Cui, J., \& Chisti, Y. (2003). Polysaccharopeptides of Coriolus versicolor: physiological activity, uses, and production. Biotechnology advances, 21(2), 109-122. http://dx.doi.org/10.1016/S0734-9750(03)00002-8

Dhanasekaran, S., Biswas, M., Vignesh, A. R., Ramya, R., Raj, G. D., Tirumurugaan, K. G., ... \& Subbiah, E. (2014). Toll-like receptor responses to Peste des petits ruminants virus in goats and water buffalo. PloS one, 9(11), e111609. http://dx.doi.org/10.1371/journal.pone.0111609

Ekwemalor, K. (2015). The Effect of a Mushroom (Coriolus versicolor) Based Probiotic on Innate immunity in Goats Naturally Infected with Gastrointestinal Parasites (Doctoral dissertation, North Carolina Agricultural and Technical State University).Goyal, S., Dubey, P. K., Tripathy, K., Mahajan, R., Pan, S., Dixit, S. P., \& Kataria, R. S. (2012). Detection of polymorphism and sequence characterization of Toll-like receptor 7 gene of Indian goat revealing close relationship between ruminant species. Animal biotechnology, 23(3), 194-203. http://dx.doi.org/10.1080/ 10495398.2012.684417

Han, S. B., Yoon, Y. D., Ahn, H. J., Lee, H. S., Lee, C. W., Yoon, W. K., ... Kim, H. M. (2003). Toll-like receptor-mediated activation of $\mathrm{B}$ cells and macrophages by polysaccharide isolated from cell culture of 
Acanthopanax senticosus. International immunopharmacology, 3(9), 1301-1312. http://dx.doi.org/10.1016/S1567-5769(03) 00118-8

Janeway Jr, C. A., \& Medzhitov, R. (2002). Innate immune recognition.Annual review of immunology, 20(1), 197-216. http://dx.doi.org/10.1146/annurev.immunol.20.083001.084359

Jung, I. L. (2014). Soluble extract from Moringa oleifera leaves with a new anticancer activity. PloS one, 9(4), e95492. http://dx.doi.org/10.1371/journal.pone.0095492

Kang, S. C., Koo, H. J., Park, S., Lim, J. D., Kim, Y. J., Kim, T., ... \& Sohn, E. H. (2013). Effects of $\beta$-glucans from Coriolus versicolor on macrophage phagocytosis are related to the Akt and CK2/Ikaros. International journal of biological macromolecules, 57, 9-16. http://dx.doi.org/10.1016/j.ijbiomac.2013.03.017

Kumagai, Y., \& Akira, S. (2010). Identification and functions of pattern-recognition receptors. Journal of Allergy and Clinical Immunology, 125(5), 985-992. http://dx.doi.org/10.1016/j.jaci.2010.01.058

Kwong, L. S., Parsons, R., Patterson, R., Coffey, T. J., Thonur, L., Chang, J. S., ... \& Hope, J. C. (2011). Characterisation of antibodies to bovine toll-like receptor (TLR)-2 and cross-reactivity with ovine TLR2. Veterinary immunology and immunopathology, 139(2), 313-318. http://dx.doi.org/10.1016/j.vetimm.2010. 10.014

Liao, S. C., Cheng, Y. C., Wang, Y. C., Wang, C. W., Yang, S. M., Yu, C. K., ... \& Shieh, J. M. (2004). IL-19 induced Th2 cytokines and was up-regulated in asthma patients. The Journal of Immunology, 173(11), 6712-6718. http://dx.doi.org/10.4049/jimmunol.173.11.6712

Liu, Q., Dong, L., Li, H., Yuan, J., Peng, Y., \& Dai, S. (2016). Lentinan mitigates therarubicin-induced myelosuppression by activating bone marrow-derived macrophages in an MAPK/NF- $\mathrm{kB}-$ dependent manner. Oncology reports, 36(1), 315-323. http://dx.doi.org/10.3892/or.2016.4769

Livak, K. J., \& Schmittgen, T. D. (2001). Analysis of relative gene expression data using real-time quantitative PCR and the 2- $\Delta \Delta$ CT method. Methods, 25(4), 402-408. http://dx.doi.org/10.1006/meth.2001.1262

Lull, C., Wichers, H. J., \& Savelkoul, H. F. (2005). Antiinflammatory and immunomodulating properties of fungal metabolites. Mediators of inflammation, 2005(2), 63-80. http://dx.doi.org/10.1155/MI.2005.63

LY Eliza, W., K Fai, C., \& P Chung, L. (2012). Efficacy of Yun Zhi (Coriolus versicolor) on survival in cancer patients: systematic review and meta-analysis. Recent patents on inflammation \& allergy drug discovery, 6(1), 78-87. http://dx.doi.org/10.2174/187221312798889310

Prince, L. R., Whyte, M. K., Sabroe, I., \& Parker, L. C. (2011). The role of TLRs in neutrophil activation. Current opinion in pharmacology, 11(4), 397-403. http://dx.doi.org/10.1016/j.coph.2011.06.007

Raja, A., Vignesh, A. R., Mary, B. A., Tirumurugaan, K. G., Raj, G. D., Kataria, R., ... \& Kumanan, K. (2011). Sequence analysis of Toll-like receptor genes 1-10 of goat (Capra hircus). Veterinary immunology and immunopathology, 140(3), 252-258. http://dx.doi.org/10.1016/j.vetimm.2011.01.007

Rowan, N. J., Smith, J. E., \& Sullivan, R. (2003). Immunomodulatory activities of mushroom glucans and polysaccharide-protein complexes in animals and humans (a review). International Journal of Medicinal Mushrooms, 5(2). http://dx.doi.org/10.1615/InterJMedicMush.v5.i2.10

Sasai, M., \& Yamamoto, M. (2013). Pathogen recognition receptors: ligands and signaling pathways by Toll-like receptors. International reviews of immunology, 32(2), 116-133. http://dx.doi.org/10.3109/08830185.2013. 774391

Schaim, O. W., Jain, N. C., \& Carrol, E. J. (1975). Veterinary Haematology. Lea Febiger Philadelphia USA.

Tirumurugaan, K. G., Dhanasekaran, S., Raj, G. D., Raja, A., Kumanan, K., \& Ramaswamy, V. (2010). Differential expression of toll-like receptor mRNA in selected tissues of goat (Capra hircus). Veterinary immunology and immunopathology, 133(2), 296-301. http://dx.doi.org/10.1016/j.vetimm.2009.08.015

Tsang, K. W., Lam, C. L., Yan, C., Mak, J. C., Ooi, G. C., Ho, J. C., ... \& Lam, W. K. (2003). Coriolus versicolor polysaccharide peptide slows progression of advanced non-small cell lung cancer. Respiratory medicine, 97(6), 618-624. http://dx.doi.org/10.1053/rmed.2003.1490

West, A. P., Koblansky, A. A., \& Ghosh, S. (2006). Recognition and signaling by toll-like receptors. Annu. Rev. Cell Dev. Biol., 22, 409-437. http://dx.doi.org/10.1146/annurev.cellbio.21.122303.115827 
Worku, M., Abdalla, A., Adjei-Fremah, S., \& Ismail, H. (2016). The Impact of Diet on Expression of Genes Involved in Innate Immunity in Goat Blood. Journal of Agricultural Science, 8(3), 1. http://dx.doi.org/10. 5539/jas.v8n3p1

Yamashiro, S., Kamohara, H., Wang, J. M., Yang, D., Gong, W. H., \& Yoshimura, T. (2001). Phenotypic and functional change of cytokine-activated neutrophils: inflammatory neutrophils are heterogeneous and enhance adaptive immune responses. Journal of leukocyte biology, 69(5), 698-704. http://dx.doi.org/10. $1159 / 000071555$

Yang, S. F., Zhuang, T. F., Si, Y. M., Qi, K. Y., \& Zhao, J. (2015). Coriolus versicolor mushroom polysaccharides exert immunoregulatory effects on mouse B cells via membrane Ig and TLR-4 to activate the MAPK and NF-kB signaling pathways. Molecular immunology, 64(1), 144-151. http://dx.doi.org/10.1016/j.molimm. 2014.11.007

Zhou, H., \& Hickford, J. G. H. (2008). Allelic polymorphism of the caprine calpastatin (CAST) gene identified by PCR-SSCP. Meat science, 79(2), 403-405. http://dx.doi.org/10.1016/j.meatsci.2007.10.015

Zhou, L., Ivanov, I. I., Spolski, R., Min, R., Shenderov, K., Egawa, T., \& Littman, D. R. (2007). IL-6 programs TH-17 cell differentiation by promoting sequential engagement of the IL-21 and IL-23 pathways. Nature immunology, 8(9), 967-974. http://dx.doi.org/10.1038/ni1488

\section{Copyrights}

Copyright for this article is retained by the author(s), with first publication rights granted to the journal.

This is an open-access article distributed under the terms and conditions of the Creative Commons Attribution license (http://creativecommons.org/licenses/by/4.0/). 